\title{
Calculation of Consumption and Expenditures for Electricity Energy Costs at Lido Graha Hotel Lhokseumawe City Based on Electrical Power Measurement
}

\author{
Arnawan Hasibuan ${ }^{1,2}$, Widyana Verawaty Siregar $^{3}$, Elvy Sahnur Nasution ${ }^{4}$, Rohana Ismail $^{5}$ \\ ${ }^{1}$ School of Electrical Engineering, Universiti Malaysia Perlis, Malaysia \\ ${ }^{2}$ School of Electrical Engineering, Universitas Malikussaleh, Indonesia \\ ${ }^{3}$ School of Management, Universitas Malikussaleh, Indonesia \\ ${ }^{4,5}$ School of Electrical Engineering, Universitas Muhammadiyah Sumatera Utara, Indonesia
}

\begin{abstract}
Article Info
Article history:

Received Jun 29, 2020

Revised Aug 05, 2020

Accepted Aug 17, 2020

Keywords:

Energy audit

Building hotel

Electrical energy

Electricity consumption

ABSTRACT

Evaluation of energy utilization and identification become energy saving opportunities, as well as recommendations for increasing efficiency, on energy use and use of energy sources in the context of energy conservation This paper aims to describe the audit of electrical energy in the Lido Graha Lhokseumawe Hotel room, by taking samples in different room types and conducting an electrical energy audit on the use of installed lights and air conditioners. The method used in this study is data collection, interviews, observations and direct measurements on the use of lights and AC (Air Conditioning). The data analysis technique used is to determine the estimated value of electricity consumption and how much it will cost for electricity. From the results of calculations and analysis obtained total electricity consumption needs based on the type of room with various types of loads used $855.62 \mathrm{kWh} /$ days with costs that must be spent per day is IDR $1,190,574.96,25,668.6 \mathrm{kWh} / \mathrm{month}$ with a monthly cost of IDR $35,087,608.60$. Whereas for a year electricity demand is $308,494.8 \mathrm{kWh} /$ year with a cost of IDR 421,051,305.24.
\end{abstract}

This is an open access article under the CC BY-SAlicense.

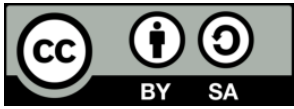

\section{Corresponding Author:}

Arnawan Hasibuan,

School of Electrical Engineering,

Universitas Malikussaleh, Indonesia

Kampus Unimal Bukit Indah Kota Lhokseumawe, Provinsi Aceh

Email: arnawan@unimal.ac.id

\section{INTRODUCTION}

Hospitality is a service business that requires large electrical energy. Hotel operation is providing services to consumers who use the facilities in the hotel [1]. To provide the highest quality service is closely related to energy use [2] [3]. The most competitive energy used in hotel operations is electricity. Hotel operating costs in terms of energy purchases range from $30 \%$, this shows that the cost for energy is very high. According to [4] [5] [6] [7], energy consumption for lighting, temperature regulation systems (air conditioning), and water heating systems generally account for $70 \%$ of the total energy use in hotel buildings.

Lido Graha Hotel, is one of the big hotels in the city of Lhokseumawe which certainly requires quite large electrical energy. With a building area of around 1 hectare and has a building with 4 floors, the Lido Graha Hotel certainly uses a lot of electrical energy. The problem to be examined 
in this paper is how efficient the use of electrical energy in the Lido Graha Hotel when it is adapted to existing electrical equipment [8]. This was done because the Lido Graha Hotel is a hotel that has long operated in the city of Lhokseumawe, so there needs to be an analysis of the use of electrical energy available. The number of visitors that fluctuates every day can change the amount of electrical energy used. Activities or events carried out at the Lido Graha hotel at any time will lead to an increase in the capacity of using different electrical energy. However, this change in usage is sometimes not adjusted to the level of Energy Consumption Intensity.

The energy cost component in a hotel is usually expressed in terms of the cost per room sold, or the total number of hotel rooms [5]. Ideally, the calculation of energy costs is carried out every day in support of energy saving programs. This can also be used to help plan for a gradual reduction in energy consumption in hotel rooms [9], or as part of an overall environmental awareness progra. In its calculation, energy costs in hotels use the formulation (1):

$$
\text { Energy cost }=\frac{\text { The total cost of electricity }(\mathrm{KWh})}{\text { Total rooms sold }}
$$

Acording to [10] energy management includes increasing in profitability due to the reduced operational costs and it is also a potential for improved market share. But there have not been so many systematic approaches to comparing the relative efficiency of the system [11]. Data envelopment analysis is a special linear programming model for obtaining comparative efficiency of multi input multi output in decision making.

\section{RESEARCH METHOD}

\subsection{Data collection technique}

The data collection technique used in this research is a descriptive study that will explain descriptively about the electrical energy requirements at Lido Graha Lhokseumawe Hotel in 2016. Descriptive research is aimed at gathering actual information in detail that describes existing symptoms, identifies problems or checks conditions and applicable practices, makes comparisons or evaluations, determines what other people do in dealing with similar problems and learns from their experiences to establish plans and decisions in the future [12]. Data collection techniques that will be used in this study are as follows [13]:

a. Observation for data collection where observation is focused on describing and explaining research phenomena.

b. Face to face interview to dig up information from respondents.

c. Secondary data documentation as a complement to primary data by studying and analyzing relevant books or information from various sources related to research studies.

Descriptive data analysis techniques [14] [15] that have been carried out include three activities, namely:

a. Collecting data, we have recorded all data objectively and in accordance with field observations and interviews.

b. Reduction of procedures, the selection process, concentration, attention, abstracting and transformation of rough data has been carried out from the field.

c. Presentation of data, has shown information arranged for analysis as material to draw conclusions and take action.

d. Verification or drawing conclusions, set conclusions written based on the results of the analysis during the study took place from the measurement and compliance with conditions in the field

\subsection{Energy Consumption Data}

The consumption of electrical energy obtained from surveys to hotel [16] [17] locations is as follows:

a. Documentation of hotel buildings, and room layout, kitchen, meeting rooms, etc. where there is electricity as lighting. 
b. Data type of equipment used at Lido Graha Hotel.

c. Data for payment of monthly electricity bills last year.

d. Data on the number of occupancy rates per month during the past year, the data can be categorized as details of building area and total building area $\left(\mathrm{m}^{2}\right)$, total electricity needed, installed electrical power per $\mathrm{m}^{2}$ floor area for the whole building, energy consumption building and hotel building energy usage costs.

\subsection{Room Size Data and Equipment Used}

Room sizes and types of equipment used at Lido Graha Hotel are shown in Table 1 and Table 2.

\begin{tabular}{|c|c|c|}
\hline Room Type & $\begin{array}{l}\text { Number } \\
\text { of room }\end{array}$ & $\begin{array}{l}\text { Room } \\
\text { size }\left(\mathrm{m}^{2}\right)\end{array}$ \\
\hline Suite Room & 4 & $6 \times 5$ \\
\hline Superior & 50 & $5 \times 5$ \\
\hline Standart & 6 & $4 \times 4$ \\
\hline Office & 5 & $4 \times 5$ \\
\hline
\end{tabular}

Table 2. Equipment used

\begin{tabular}{ll}
\hline Type of Equipment & \multicolumn{1}{c}{ Brand } \\
\hline Air Conditioning & Panasonic dan LG \\
Lighting & Philip dan Hannocs \\
Television & Panasonic and Sharp \\
Chiller Pump & Sanyo \\
\hline
\end{tabular}

\subsection{Consumption of Electric Power and Electric Energy}

The electrical power installed at the Lido Graha Hotel can be seen in Table 3 to Table 7.

Table 3. Lamp power data

\begin{tabular}{|c|c|c|c|c|c|c|}
\hline \multirow{3}{*}{$\begin{array}{l}\text { Room } \\
\text { Type }\end{array}$} & \multirow{3}{*}{$\begin{array}{l}\text { Number } \\
\text { of rooms }\end{array}$} & \multicolumn{4}{|c|}{ Bulb type } & \multirow{3}{*}{$\begin{array}{c}\text { Duration } \\
\text { (hours) }\end{array}$} \\
\hline & & \multicolumn{2}{|c|}{ HE } & \multicolumn{2}{|c|}{ Hallogen } & \\
\hline & & $\begin{array}{c}\text { Power } \\
\text { (W) }\end{array}$ & $\begin{array}{l}\text { Number } \\
\text { of bulb }\end{array}$ & $\begin{array}{c}\text { Power } \\
(\mathbf{W})\end{array}$ & $\begin{array}{c}\text { Number } \\
\text { of bulb }\end{array}$ & \\
\hline Suite Room & 4 & 60 & 4 & 42 & 2 & 9 \\
\hline Superior & 50 & 55 & 3 & 20 & 2 & 9 \\
\hline Standart & 6 & 50 & 3 & 20 & 1 & 9 \\
\hline Restaurant & 1 & 75 & 6 & 150 & 1 & 9 \\
\hline Kitchen & 1 & 75 & 5 & - & - & 9 \\
\hline
\end{tabular}

Table 4. Television data

\begin{tabular}{lcccc}
\hline $\begin{array}{c}\text { Room } \\
\text { Type }\end{array}$ & $\begin{array}{c}\text { Number } \\
\text { of rooms }\end{array}$ & $\begin{array}{c}\text { Size } \\
\text { (Inch) }\end{array}$ & $\begin{array}{c}\text { Power of } \\
\text { Television } \\
\text { (W) }\end{array}$ & $\begin{array}{c}\text { Duration } \\
\text { (hours) }\end{array}$ \\
\hline Suite Room & 4 & 24 & 100 & 5 \\
Superior & 50 & 22 & 100 & 5 \\
Standart & 6 & 21 & 100 & 5 \\
\hline
\end{tabular}

Table 5. Air conditioner data

\begin{tabular}{lccc}
\hline $\begin{array}{c}\text { Room } \\
\text { Type }\end{array}$ & $\begin{array}{c}\text { Number } \\
\text { of rooms }\end{array}$ & $\begin{array}{c}\text { Power of Air } \\
\text { Conditioner (W) }\end{array}$ & $\begin{array}{c}\text { Duration } \\
\text { (hours) }\end{array}$ \\
\hline Suite Room & 4 & 1.119 & 14 \\
Superior & 50 & 660 & 14 \\
Standart & 6 & 660 & 14 \\
Office & 5 & 660 & 9 \\
\hline \multicolumn{4}{c}{} \\
& Table 6. Water heater data \\
\hline Room & Number & Power of & Duration \\
Type & of rooms & Water Heater (W) & (hours) \\
\hline Suite Room & 4 & 1.250 & 01 \\
Superior & 50 & 1.250 & 1 \\
Standart & 6 & 1.250 & 1 \\
\hline
\end{tabular}




\begin{tabular}{cccc}
\multicolumn{4}{c}{ Table 7. Water pump data } \\
\hline $\begin{array}{c}\text { Points } \\
\text { of use }\end{array}$ & Total & $\begin{array}{c}\text { Power of } \\
\text { Water Heater (W) }\end{array}$ & $\begin{array}{c}\text { Duration } \\
\text { (hours)/month }\end{array}$ \\
\hline Swimming pool & 2 & 1.100 & 12 \\
\hline
\end{tabular}

\subsection{Cost of Electric Energy Consumption}

Electrical energy at the Lido Graha Hotel uses electricity sourced from the state electricity company (PLN). The cost of electricity in the past year can be seen in Table 8 .

Table 8. Consumption and Cost of Electrical Energy at Lido Graha Hotel in 2016

\begin{tabular}{clcc}
\hline Number & Month & $\begin{array}{c}\text { Total electricity } \\
\text { Consumption (kWh)/month }\end{array}$ & Cost \\
\hline 1 & Januari & 47005,78 & IDR 63,551,812 \\
2 & Februari & 34876,51 & IDR 47,153,047 \\
3 & Maret & 31290,02 & IDR 42,304,109 \\
4 & April & 34798,94 & IDR 47,048,171 \\
5 & Mei & 45218,33 & IDR 61,135,181 \\
6 & Juni & 40581,35 & IDR 54,865,991 \\
7 & Juli & 23364,76 & IDR 31,589,162 \\
8 & Agustus & 27513,77 & IDR 37, 198,611 \\
9 & September & 38152,28 & IDR 51,581,887 \\
10 & Oktober & 34784,98 & IDR 47,029,299 \\
11 & November & 40951,99 & IDR 55,367,096 \\
12 & Desember & 43811,85 & IDR 59,233,620 \\
\hline
\end{tabular}

\section{RESULTS AND DISCUSSION}

Based on Table 8, it can be seen that the biggest electricity consumption in January is IDR $63,551,812.00$, this is because there are activities in almost all rooms filled with many local government agendas held at the hotel, namely training events, political party conventions, new year's agenda, maulidurrasul, and also the activity of the holidays, so that the use of electricity loads and costs incurred also high. The smallest electricity consumption occurred in July, amounting to IDR $31,589,162.00$. This month, the consumption of electricity was relatively small due to the lack of consumption at the hotel, as well as other activities such as training, congresses, regional political party meetings, which were reduced compared to other months. The total amount of electricity consumption costs with various types of loads and activities that operate 24-hour diving must be paid an average of IDR 49,821,499.00 per month, while the costs for a year are IDR $597,857,986.00$.

\subsection{Results of measurements of daily load characteristics at Lido Graha Hotel}

The results of measurements of daily load characteristics at Lido Graha Hotel are listed in table 9 and table 10.

Table 9. Voltage values in the electrical system of Lido Graha Lhokseumawe Hotel

\begin{tabular}{lccc}
\hline \multirow{2}{*}{ Voltage } & \multicolumn{3}{c}{ Phasa (Volt) } \\
\cline { 2 - 4 } & $\mathbf{V}_{\text {R-N }}$ & $\mathbf{V}_{\text {S-N }}$ & $\mathbf{V}_{\text {T-N }}$ \\
\hline Maximum & 229 & 230 & 231 \\
Minimum & 225 & 225 & 225 \\
Average & 227 & 227,5 & 228 \\
\hline
\end{tabular}

Table 10. Current values in the electrical system of Lido Graha Lhokseumawe Hotel

\begin{tabular}{lccc}
\hline \multirow{2}{*}{ Current } & \multicolumn{3}{c}{ Phasa (Ampere) } \\
\cline { 2 - 4 } & $\mathbf{I}_{\mathbf{R}}(\mathbf{A})$ & $\mathbf{I}_{\mathbf{S}}(\mathbf{A})$ & $\mathbf{I}_{\mathbf{T}}(\mathbf{A})$ \\
\hline Maximum & 48,5 & 50,5 & 40,6 \\
Minimum & 24,2 & 22,5 & 22,8 \\
Average & 36,5 & 36,5 & 31,7 \\
\hline
\end{tabular}

\subsection{Evaluation of electrical power requirements and intensity of electrical energy consumption}

The data obtained that shows the characteristics of the use of electrical energy to be observed and calculated how much the burden of costs that must be incurred daily, monthly, and annual costs. 
Table 11. Characteristics of electricity consumption in Lido Graha Hotel

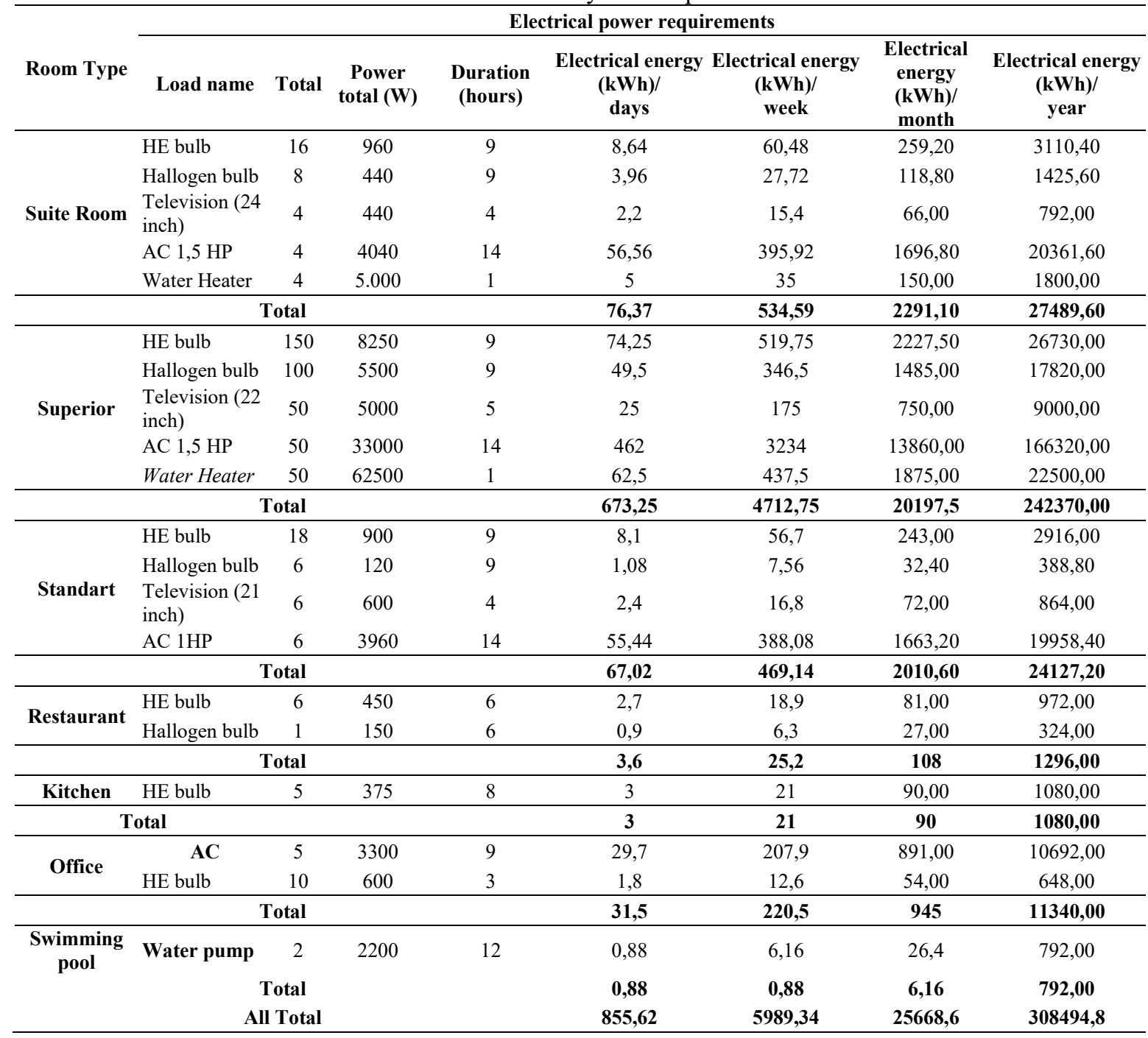

Furthermore, the cost calculation is based on the basic electricity tariff

Table 12. Lido Graha Hotel electricity payment

\begin{tabular}{|c|c|c|c|c|}
\hline \multirow{2}{*}{ Room Type } & \multirow{2}{*}{$\begin{array}{c}\text { Electrical energy } \\
(\mathrm{kWh}) / \text { days }\end{array}$} & \multicolumn{3}{|c|}{ Cost of electric energy } \\
\hline & & IDR/days & IDR/month & IDR/years \\
\hline Suite Room & 76,37 & IDR $103,238.72$ & IDR 3,097,161.60 & IDR $37,165,939.20$ \\
\hline Superior & 673,25 & IDR 910,234.00 & IDR $27,307,020.00$ & IDR $327,684,240.00$ \\
\hline Standart & 67,02 & IDR 90,611.04 & IDR $2,718,331.00$ & IDR $32,619,974.04$ \\
\hline Restaurant & 3,6 & IDR 4,867.20 & IDR $146,016.00$ & IDR $1,752,192.00$ \\
\hline Kitchen & 3 & IDR $4,056.00$ & IDR $121,680.00$ & IDR $1,460,160.00$ \\
\hline Office & 31,5 & IDR $42,588.00$ & IDR $1,277,640.00$ & IDR $15,331,680.00$ \\
\hline Swimming pool & 26.4 & IDR $34,980.00$ & IDR 419,760.00 & IDR $5,037,120.00$ \\
\hline \multicolumn{2}{|c|}{ Total } & IDR $1,190,574.96$ & IDR $35,087,608.60$ & IDR $421,051,305.24$ \\
\hline
\end{tabular}

Based on the amount of electrical energy consumption in accordance with the use of the Lido Graha Hotel which operates 24 hours a day, shown in table 11, it can be seen that the largest amount of electrical energy consumption is in the Superior room due to the number of rooms 
reaching 50 rooms. And the smallest amount of electrical energy consumption is found in the kitchen room because the load used is only 3 HE bulbs.

The total electricity consumption needs based on the type of room with various types of loads used $855.62 \mathrm{kWh} /$ days with costs that must be spent per day is IDR 1,190,574.96, 25,668.6 $\mathrm{kWh} /$ month with a monthly cost of IDR $35,087,608.60$. Whereas for a year electricity demand is $308,494.8 \mathrm{kWh} /$ year with a cost of IDR 421,051,305.24.

\section{CONCLUSION}

The conclusions that can be summarized from the measurements and calculations that have been made are as follows:

1. The results of inter-phase voltage measurements on the electrical system at the Lido Graha Lhokseumawe Hotel are worth between 225-231 V.

2. The measurement results of the measured current value are between 22.5-50.5 A, while the peak load occurs at 1018: 30-23: 45 WIB.

3. The results of the calculation of electricity consumption needs are $855.62 \mathrm{kWh} /$ days, and $25,668.6 \mathrm{kWh} /$ month, while for a year it is $308,494.8 \mathrm{kWh} /$ year.

4. The cost of electricity that must be spent on average per month is IDR $35,087,608.60$, and for a year is IDR $421,051,305.24$.

\section{ACKNOWLEDGEMENTS}

This work would not have been possible without the support of my students who helped with data collection. I thank all parties who have worked together so far and who are related to this paper.

\section{REFERENCES}

[1] Y. Narangajavana and B. Hu, "The relationship between the hotel rating system, service quality improvement, and hotel performance changes: A canonical analysis of hotels in Thailand," J. Qual. Assur. Hosp. Tour., vol. 9, no. 1, pp. 34-56, 2008.

[2] A. Marzuki and others, "Audit Energi pada Bangunan Gedung Direksi PT. Perkebunan Nusantara XIII (Persero)," 2013.

[3] J. R. Galvão, S. A. Leitão, S. M. Silva, and T. M. Gaio, "Cogeneration supply by bio-energy for a sustainable hotel building management system," Fuel Process. Technol., vol. 92, no. 2, pp. 284-289, 2011.

[4] Y. Zhu and H. Adler, "Chinese Hotel General Managers' Perspectives on Energy Saving Practices," 2011.

[5] J. Xing, P. Ren, and J. Ling, "Analysis of energy efficiency retrofit scheme for hotel buildings using eQuest software: A case study from Tianjin, China," Energy Build., vol. 87, pp. 14-24, 2015.

[6] P. Bohdanowicz, A. Churie-Kallhauge, I. Martinac, and D. Rezachek, "Energy-efficiency and conservation in hotels--towards sustainable tourism," $4^{\circ}$ Simpósio Int. em Arquitetura da Ásia e $\left.P a c\{|'| i\} f i c o, \operatorname{Hava}_{\{}\left|{ }^{\prime}\right| i\right\}, 2001$.

[7] F. Fazelpour, N. Soltani, and M. A. Rosen, "Feasibility of satisfying electrical energy needs with hybrid systems for a medium-size hotel on Kish Island, Iran," Energy, vol. 73, pp. 856-865, 2014.

[8] Ó. Garcl'lia, R. S. Alonso, D. I. Tapia, and J. M. Corchado, "Electrical power consumption monitoring in hotels using the n-Core Platform," in 2016 Clemson University Power Systems Conference (PSC), 2016, pp. 1-6.

[9] E. R. Mauboy and others, "Audit Energi Listrik pada Hotel Sotis Kupang," Media Elektro, pp. 149154, 2019.

[10] S. Önüt and S. Soner, "Energy efficiency assessment for the Antalya Region hotels in Turkey," Energy Build., vol. 38, no. 8, pp. 964-971, 2006.

[11] J. Guan and K. Chen, "Modeling the relative efficiency of national innovation systems," Res. Policy, vol. 41, no. 1, pp. 102-115, 2012.

[12] A. Fraser, B. Delaney, and P. Moayyedi, "Symptom-based outcome measures for dyspepsia and GERD trials: a systematic review," Am. J. Gastroenterol., vol. 100, no. 2, pp. 442-452, 2005.

[13] K. N. Barker, "Data collection techniques: observation," Am. J. Hosp. Pharm., vol. 37, no. 9, pp. $1235-1245,1980$. 
[14] G. Michailidis and J. De Leeuw, "The Gifi system of descriptive multivariate analysis," Stat. Sci., pp. 307-336, 1998.

[15] A. W. Hafner, Descriptive statistical techniques for librarians. ERIC, 1998.

[16] F. W. H. Yik, J. Burnett, and I. Prescott, "Predicting air-conditioning energy consumption of a group of buildings using different heat rejection methods," Energy Build., vol. 33, no. 2, pp. 151-166, 2001.

[17] I. Knight, S. Stravoravdis, and S. Lasvaux, "Predicting operational energy consumption profilesFindings from detailed surveys and modelling in a UK educational building compared to measured consumption," Int. J. Vent., vol. 7, no. 1, pp. 49-57, 2008. 